\title{
Notas Científicas
}

\section{Stomatal conductance of maize under water and nitrogen deficits}

\author{
Leonardo Oliveira Medici(1), Ricardo Antunes Azevedo(2), Luciano Pasqualoto Canellas ${ }^{(3)}$, \\ Altair Toledo Machado ${ }^{(4)}$ and Carlos Pimentel|(5)
}

\begin{abstract}
(1)Universidade Federal Rural do Rio de Janeiro (UFRRJ), Dep. de Ciências Fisiológicas, CEP 23890-000 Seropédica, RJ, Brazil. E-mail: Iomedici@ufrrj.br (2)Escola Superior de Agricultura Luiz de Queiroz, Dep. de Genética, Caixa Postal 9, CEP 13418-900 Piracicaba, SP, Brazil. E-mail: raazeved@esalq.usp.br (3)Universidade Estadual do Norte Fluminense, Lab. de Solos, CEP 28013-602 Campos dos Goytacazes, RJ, Brazil. E-mail: canellas@uenf.br ${ }^{(4)}$ Embrapa Cerrados, Caixa Postal 08223, CEP 73301-970 Planaltina, DF, Brazil. E-mail: altair@cpac.embrapa.br (5)UFRRJ, Dep. de Fitotecnia. E-mail: greenman@amcham.com.br
\end{abstract}

\begin{abstract}
The objective of this work was to evaluate the effect of drought and nitrogen $(\mathrm{N})$ stresses on stomatal conductance of three maize cultivars grown in the field. The stomatal conductance of Sol da Manhã variety (BRS 4157) and Pioneer 6875 hybrid, under drought and high N, was lower than under drought and low N, which indicates drought tolerance, since these cultivars did not exhibit reduction in grain yield by drought, as observed for Amarelão variety, which flowered under more severe drought. 'Sol da Manhã' exhibited shorter anthesissilking interval under high $\mathrm{N}$ than under low $\mathrm{N}$, an additional indication of tolerance.
\end{abstract}

Index terms: Zea mays, drought tolerance, anthesis-silking interval.

\section{Condutância estomática em milho em condições de deficiência de água e nitrogênio}

\begin{abstract}
Resumo - O objetivo deste trabalho foi avaliar o efeito do deficit hídrico e de nitrogênio $(\mathrm{N})$ sobre a condutância estomática, em três cultivares de milho cultivadas em campo. A condutância estomática da variedade Sol da Manhã (BRS 4157) e do híbrido Pioneer 6875, em condições de seca e alto teor de N, foi menor que com seca e baixo teor N, o que indica tolerância à seca, pois estas cultivares não tiveram a produção de grãos reduzida com a seca, como ocorreu com a variedade Amarelão, que floresceu sob condições de seca mais severa. 'Sol da Manhã' exibiu maior sincronia entre pendoamento e espigamento com alto teor de $\mathrm{N}$ do que com baixo $\mathrm{N}$, o que é evidência adicional de tolerância.
\end{abstract}

Termos para indexação: Zea mays, tolerância à seca, sincronia de florescimento.

Water and nitrogen $(\mathrm{N})$ deficits are the most important limitations to crops production (Lea \& Azevedo, 2006; Pimentel, 2006). However, most of the studies have focused on either water or $\mathrm{N}$ deficits separately, but only a few have addressed the complex interactions between these abiotic stresses (Bänziger et al., 2002; Moser et al., 2006).

The control of leaf stomatal conductance $\left(\mathrm{g}_{\mathrm{s}}\right)$ is a crucial mechanism for plants, since it is essential for both $\mathrm{CO}_{2}$ acquisition and desiccation prevention (Dodd, 2003). Studies with maize have shown that some drought tolerant genotypes reduce $\mathrm{g}_{\mathrm{s}}$ more on the onset of drought (Paterniani, 1990; Ray \& Sinclair, 1997), whilst the effect of $\mathrm{N}$ deficit on $\mathrm{g}_{\mathrm{s}}$ includes several interactions, such as decreases (Dodd, 2003), increases or no effect (Cechin $\&$ Fumis, 2004). This study aimed to evaluate the importance of $g_{s}$ for tolerance to the combinations of water and $\mathrm{N}$ deficits in maize.

Three maize (Zea mays L.) cultivars were used: the hybrid P6875 from Pioneer, the variety Amarelão originated from the Brazilian Semiarid Region, and the variety Sol da Manhã (BRS 4157) improved for N use efficiency (Machado \& Fernandes, 2001). The three cultivars were sown together on May $30^{\text {th }}$, and the hybrid was sown again 10 days later, as an additional treatment, to allow the observation of effects of drought at the same stage for the three cultivars, and in different stages for the hybrid, which exhibited earlier flowering when compared to the other cultivars. The hybrid sown first is referred in the text as "P6875F", whereas the one sown later is referred as "P6875D". 
The experiment was carried out at PESAGRO Experimental Station of Itaguaí, Rio de Janeiro, Brazil. The field used had several beds separated from each other by walls of bricks and cement, with $0.6 \mathrm{~m}$ depth, which allowed the placement of well-irrigated plots sideby-side with drought plots, as well as high and low $\mathrm{N}$ supply treatments. The plots consisted of one-row, $2.5 \mathrm{~m}$ long, with plants spaced $0.2 \mathrm{~m}$ within-row.

On July $1^{\text {st }}$, the plots sowed first and treated with the low $\mathrm{N}$ level received $20 \mathrm{~kg} \mathrm{ha}^{-1} \mathrm{~N}$ as urea. The plots treated with high $\mathrm{N}$ level received $50 \mathrm{~kg} \mathrm{ha}^{-1} \mathrm{~N}$ as urea on July $1^{\text {st }}$, and $50 \mathrm{~kg} \mathrm{ha}^{-1} \mathrm{~N}$ on July $7^{\text {th }}$. The plots of the second sowing date received the same $\mathrm{N}$ fertilizer distribution on July $9^{\text {th }}$ and $17^{\text {th }}$.

Drought was imposed by withholding irrigation 64 days after sowing (DAS), on August $1^{\text {st }}$, and plastic covers were used to cover the drought plots on rainy days. At $100^{\text {th }}$ DAS, the drought treatment was ended by resuming irrigation. The irrigated plots were maintained close to the field capacity using tensiometers placed at $20 \mathrm{~cm}$ depth in the soil.

Soil humidity (w/w) was measured weekly, during the drought period, and water potential $\left(\Psi_{\mathrm{w}}\right)$ was calculated by using previously performed pressure $\mathrm{x}$ humidity curves. In the soil depth from 15 to $20 \mathrm{~cm}$, the soil humidity was $9.9,8.5,7.1$, and $5.1 \%$ at $64,71,78$ and $85^{\text {th }}$ DAS, respectively. In the soil depth from 20 to $40 \mathrm{~cm}$, soil humidity was 5 and $4.8 \%$ at 85 and $100^{\text {th }}$ DAS, respectively, whereas in the soil depth from 40 to $60 \mathrm{~cm}$, soil humidity was 4.7 at $100^{\text {th }}$ DAS. The $\Psi_{\mathrm{w}}$ obtained in the soil depth from 15 to $20 \mathrm{~cm}$ were -0.19 and $-0.6 \mathrm{MPa}$, at 64 and $71^{\text {th }} \mathrm{DAS}$, respectively. All other measured humidity was related to $\Psi_{\mathrm{w}}$ values lower than -1.5 MPa.

Stomatal conductance was measured with the AP4 porometer (Delta T Company, England), in the ear leaf between 66 and $106^{\text {th }}$ DAS. Each $g_{s}$ interval measurement took around 1 hour and started at 9:00, 12:00 or 15:00 h. Photosynthetic photon flux density and air temperature means, at each $\mathrm{g}_{\mathrm{s}}$ interval measurement, were $874 \pm 456 \mu \mathrm{mol} \mathrm{m}^{-2} \mathrm{~s}^{-1}$ and $27.9 \pm 3.4^{\circ} \mathrm{C}$, respectively.

Anthesis date was considered the number of days between sowing and 50\% of plants exhibiting anther emergence, whereas anthesis-silking interval was the number of days between anthesis date and $50 \%$ of the plants exhibiting silk emergence.

The experimental design for grain yield, anthesis date and anthesis-silking interval traits was a factorial splitsplit plot with the water regime (well irrigated and drought) as the plots, in four blocks, the $\mathrm{N}$ levels as split of water regime, and maize cultivars as split of $\mathrm{N}$ levels. The experimental design for $\mathrm{g}_{\mathrm{s}}$, in each day, was the same for the other traits. The three different interval measurements were considered as blocks, and only the days with significant differences were shown in Table 1. Variance analysis and the multiple comparisons (Bonferroni test) were carried out.

Plants under drought and high $\mathrm{N}$ supply exhibited significantly lower $\mathrm{g}_{\mathrm{s}}$ than under drought and low $\mathrm{N}$ supply (Table 1). This behaviour was shown mainly on 'Sol da Manhã' and indicates drought tolerance, since this maize variety also exhibited significantly lower values of anthesissilking interval under high $\mathrm{N}$ supply than under low $\mathrm{N}$ (Table 2), which is considered an important trait, when drought and $\mathrm{N}$ stresses are concerned (Bänziger et al., 2002).

Table 1. Stomatal conductance $\left(\mathrm{mol} \mathrm{m}^{-2} \mathrm{~s}^{-1}\right)$ averages of maize cultivars, under combinations of water and nitrogen supplies $^{(1)}$.

\begin{tabular}{lcccc}
\hline Cultivar & \multicolumn{2}{c}{ Drought } & \multicolumn{2}{c}{ Irrigated } \\
\cline { 2 - 3 } \cline { 5 - 6 } & High N & Low N & High N & Low N \\
\hline Amarelão & $0.158 \mathrm{a}$ & $0.109 \mathrm{a}$ & $0.167 \mathrm{a}$ & $0.146 \mathrm{a}$ \\
Sol da Manhã & $0.101 \mathrm{~b}$ & $0.131 \mathrm{ab}$ & $0.192 \mathrm{a}$ & $0.146 \mathrm{ab}$ \\
P6875D & $0.157 \mathrm{a}$ & $0.156 \mathrm{a}$ & $0.188 \mathrm{a}$ & $0.165 \mathrm{a}$ \\
P6875F & $0.125 \mathrm{a}$ & $0.153 \mathrm{a}$ & $0.177 \mathrm{a}$ & $0.145 \mathrm{a}$ \\
\hline & \multicolumn{5}{c}{88 days after sowing } \\
Amarelão & $0.064 \mathrm{a}$ & $0.080 \mathrm{a}$ & $0.089 \mathrm{a}$ & $0.097 \mathrm{a}$ \\
Sol da Manhã & $0.063 \mathrm{~b}$ & $0.122 \mathrm{ab}$ & $0.099 \mathrm{ab}$ & $0.143 \mathrm{a}$ \\
P6875D & $0.100 \mathrm{a}$ & $0.090 \mathrm{a}$ & $0.124 \mathrm{a}$ & $0.103 \mathrm{a}$ \\
P6875F & $0.065 \mathrm{a}$ & $0.063 \mathrm{a}$ & $0.102 \mathrm{a}$ & $0.114 \mathrm{a}$ \\
\hline & \multicolumn{5}{c}{94 days after sowing } \\
Amarelão & $0.057 \mathrm{a}$ & $0.120 \mathrm{a}$ & $0.155 \mathrm{a}$ & $0.186 \mathrm{a}$ \\
Sol da Manhã & $0.064 \mathrm{~b}$ & $0.133 \mathrm{a}$ & $0.157 \mathrm{a}$ & $0.166 \mathrm{a}$ \\
P6875D & $0.052 \mathrm{~b}$ & $0.102 \mathrm{ab}$ & $0.186 \mathrm{a}$ & $0.124 \mathrm{ab}$ \\
P6875F & $0.072 \mathrm{~b}$ & $0.087 \mathrm{ab}$ & $0.160 \mathrm{a}$ & $0.189 \mathrm{a}$ \\
\hline & \multicolumn{5}{c}{96 days after sowing } \\
Amarelão & $0.073 \mathrm{~b}$ & $0.085 \mathrm{ab}$ & $0.126 \mathrm{a}$ & $0.117 \mathrm{a}$ \\
Sol da Manhã & $0.060 \mathrm{~b}$ & $0.114 \mathrm{a}$ & $0.127 \mathrm{a}$ & $0.108 \mathrm{a}$ \\
P6875D & $0.081 \mathrm{~b}$ & $0.109 \mathrm{ab}$ & $0.153 \mathrm{a}$ & $0.134 \mathrm{a}$ \\
P6875F & $0.065 \mathrm{~b}$ & $0.100 \mathrm{a}$ & $0.161 \mathrm{a}$ & $0.143 \mathrm{a}$ \\
\hline & & 98 days after sowing \\
Amarelão & $0.084 \mathrm{a}$ & $0.065 \mathrm{a}$ & $0.165 \mathrm{a}$ & $0.117 \mathrm{a}$ \\
Sol da Manhã & $0.076 \mathrm{~b}$ & $0.097 \mathrm{ab}$ & $0.158 \mathrm{a}$ & $0.114 \mathrm{a}$ \\
P6875D & $0.079 \mathrm{~b}$ & $0.070 \mathrm{~b}$ & $0.171 \mathrm{a}$ & $0.107 \mathrm{ab}$ \\
P6875F & $0.073 \mathrm{a}$ & $0.108 \mathrm{a}$ & $0.177 \mathrm{a}$ & $0.186 \mathrm{a}$ \\
\hline & & 99 days after sowing \\
Amarelão & $0.084 \mathrm{ab}$ & $0.054 \mathrm{~b}$ & $0.150 \mathrm{a}$ & $0.195 \mathrm{a}$ \\
Sol da Manhã & $0.064 \mathrm{~b}$ & $0.129 \mathrm{ab}$ & $0.166 \mathrm{a}$ & $0.125 \mathrm{ab}$ \\
P6875D & $0.065 \mathrm{a}$ & $0.122 \mathrm{a}$ & $0.190 \mathrm{a}$ & $0.109 \mathrm{a}$ \\
P6875F & $0.049 \mathrm{~b}$ & $0.111 \mathrm{a}$ & $0.199 \mathrm{a}$ & $0.187 \mathrm{a}$ \\
\hline
\end{tabular}

(1)Values within a row followed by equal letters do not differ significantly $(\mathrm{p}<0.05)$, according to Bonferroni test. 
Table 2. Grain yield, anthesis date and anthesis-silking interval averages of maize cultivars, under combinations of water and nitrogen supplies ${ }^{(1)}$.

\begin{tabular}{llllll}
\hline \multirow{2}{*}{ Cultivar } & \multicolumn{2}{c}{ Drought } & & \multicolumn{2}{c}{ Irrigated } \\
\cline { 2 - 3 } \cline { 5 - 6 } & High N & Low N & High N & Low N \\
\hline Amarelão & $3,524 \mathrm{ABb}$ & Grain yield $\left(\mathrm{kg} \mathrm{ha}^{-1}\right)$ \\
Sol da Manhã & $4,171 \mathrm{Aab}$ & $3,811 \mathrm{Aa}$ & $5,536 \mathrm{Aab}$ & $3,360 \mathrm{Bb}$ \\
P6875D & $4,334 \mathrm{Bab}$ & $3,863 \mathrm{Ba}$ & $6,648 \mathrm{Aab}$ & $3,883 \mathrm{Aab}$ \\
P6875F & $6,059 \mathrm{Aa}$ & $3,906 \mathrm{Ba}$ & $7,350 \mathrm{Aa}$ & $5,778 \mathrm{ABa}$ \\
\hline \multicolumn{4}{c}{ Anthesis date (days after sowing) } \\
Amarelão & $86.5 \mathrm{Aa}$ & $84.5 \mathrm{Aa}$ & $86.5 \mathrm{Aa}$ & $86.8 \mathrm{Aa}$ \\
Sol da Manhã & $80.0 \mathrm{Ab}$ & $80.0 \mathrm{Ab}$ & & $81.3 \mathrm{Ab}$ & $80.3 \mathrm{Ab}$ \\
P6875D & $75.8 \mathrm{Ac}$ & $75.8 \mathrm{Ac}$ & $75.0 \mathrm{Ac}$ & $75.5 \mathrm{Ac}$ \\
P6875F & $65.3 \mathrm{Bc}$ & $76.5 \mathrm{Abc}$ & $74.3 \mathrm{ABc}$ & $75.5 \mathrm{ABc}$ \\
\hline \multicolumn{5}{c}{ Anthesis-silking interval (days) } \\
Amarelão & $7.0 \mathrm{Aa}$ & $6.8 \mathrm{Aa}$ & $3.9 \mathrm{Aa}$ & $4.8 \mathrm{Aab}$ \\
Sol da Manhã & $1.5 \mathrm{Bb}$ & $5.3 \mathrm{Aa}$ & $3.0 \mathrm{ABa}$ & $6.5 \mathrm{Aa}$ \\
P6875D & $3.3 \mathrm{Aab}$ & $3.8 \mathrm{Aa}$ & $1.5 \mathrm{Aa}$ & $2.3 \mathrm{Abc}$ \\
P6875F & $3.0 \mathrm{Aab}$ & $4.0 \mathrm{Aa}$ & $1.5 \mathrm{Aa}$ & $1.5 \mathrm{Ac}$ \\
\hline
\end{tabular}

${ }^{(1)}$ Values followed by equal capital letters in the row, or equal small letters in the column, do not differ significantly $(\mathrm{p}<0.05)$, according to Bonferroni test.

Hybrid P6875F behaviour also indicates some level of tolerance to drought, due to $\mathrm{N}$ supply related to low $\mathrm{g}_{\mathrm{s}}$ since this hybrid, under drought and high $\mathrm{N}$ supply, exhibited low values of $\mathrm{g}_{\mathrm{s}}$ and early flowering, which could be considered as two different types of drought avoidance mechanisms. The $\mathrm{N}$ supply also shortened the time from emergence to tasseling in the work of Jones et al. (1986).

The hybrid P6875D began flowering when severe drought was established, but exhibited the same drought effect on anthesis-silking interval as P6875F, and such behaviour also indicates some degree of drought tolerance in this hybrid, supporting the findings of Medici et al. (2003).

The cultivar Amarelão exhibited some level of drought tolerance, since it was flowering when drought condition was more severe, and had a similar grain yield as $\mathrm{P} 6875 \mathrm{~F}$ under water and $\mathrm{N}$ deficits (Table 2).

The high $\mathrm{N}$ supply mitigated the drought effect, mainly under less severe situations, e.g., when plants flowered early during drought, as observed for P6875F. Drought effect alleviation by $\mathrm{N}$ application was also reported by Liu et al. (2004). The present work indicates that the maize genetic improvement for low $\mathrm{g}_{\mathrm{s}}$ and anthesis-silking interval, under $\mathrm{N}$ supply, could be an important approach for drought tolerance and water economy in agriculture.

\section{Aknowledgements}

To Embrapa Milho e Sorgo and Pioneer, for donation of seeds.

\section{References}

BÄNZIGER, M.; EDMEADES, G.O.; LAFITTE, H.R. Physiological mechanisms contributing to the increased $\mathrm{N}$ stress tolerance of tropical maize selected for drought tolerance. Field Crops Research, v.75, p.223-233, 2002.

CECHIN, I.; FUMIS, T. de F. Effect of nitrogen supply on growth and photosynthesis of sunflower plants grown in the greenhouse. Plant Science, v.166, p.1379-1385, 2004.

DODD, I.C. Hormonal interactions and stomatal responses. Journal of Plant Growth Regulation, v.22, p.32-46, 2003.

JONES, J.W.; ZUR, B.; BENNETT, J.M. Interactive effects of water and nitrogen stresses on carbon and water vapor exchange of corn canopies. Agricultural and Forest Meteorology, v.38, p.113-126, 1986.

LEA, P.J.; AZEVEDO, R.A. Nitrogen use efficiency. 1. Uptake of nitrogen from the soil. Annals of Applied Biology, v.149, p.243247, 2006.

LIU, X.B.; HERBERT, S.J.; JIN, J.A.; ZHANG, Q.Y.; WANG, G.H. Responses of photosynthetic rates and yield/quality of main crops to irrigation and manure application in the black soil area of Northeast China. Plant and Soil, v.261, p.55-60, 2004.

MACHADO, A.T.; FERNANDES, M.S. Participatory maize breeding for low nitrogen tolerance. Euphytica, v.122, p.567-573, 2001.

MEDICI, L.O.; MACHADO, A.T.; AZEVEDO, R.A.; PIMENTEL, C. Glutamine synthetase activity, relative water content and water potential in maize submitted to drought. Biologia Plantarum, v.47, p.301-304, 2003.

MOSER, S.B.; FEIL, B.; JAMPATONG, S.; STAMP, P. Effects of pre-anthesis drought, nitrogen fertilizer rate, and variety on grain yield, yield components, and harvest index of tropical maize. Agricultural Water Management, v.81, p.41-58, 2006.

PATERNIANI, E. Maize breeding in the tropics. Critical Reviews in Plant Sciences, v.9, p.125-154, 1990.

PIMENTEL, C. Efficiency of nutrient use by crops for low input agro-environments. In: SINGH, R.P.; SHANKAR, N.; JAIWAL, P.W. (Ed.). Focus on agriculture: nitrogen nutrition in plant productivity. Houston: Studium Press, 2006. v.1, p.277328.

RAY, J.D.; SINCLAIR, T.R. Stomatal closure of maize hybrids in response to drying soil. Crop Science, v.37, p.803-807, 1997. 